\title{
Government Size and Economic Growth: Evidence from Selected OECD Countries
}

\author{
Alice Aleksandrovich ${ }^{1} \&$ Kamal P. Upadhyaya ${ }^{2}$ \\ ${ }^{1}$ LeGarde Capital Management, New York, USA \\ ${ }^{2}$ Department of Economics, University of New Haven, Connecticut, USA \\ Correspondence: Kamal P. Upadhyaya, Department of Economics, University of New Haven, Connecticut, USA. \\ Tel: 1-203-972-7487. E-mail: Kupadhyaya@newhaven.edu
}

Received: February 16, 2015

Accepted: March 16, 2015

Online Published: April 25, 2015

doi:10.5539/ijef.v7n5p38

URL: http://dx.doi.org/10.5539/ijef.v7n5p38

\begin{abstract}
The purpose of this research is to study the impact of government size on economic growth in three OECD countries, namely the USA, Canada, and the United Kingdom. A standard growth model is developed in which capital, labor, government size, and tax revenue are included as the explanatory variables. Annual time series data from 1975 to 2012 are used to estimate the model. Since the initial estimation suffered from an autocorrelation problem, the model is estimated using an $\mathrm{AR}(1)$ term. The overall estimated results suggest that the size of government does not have any significant positive effect on economic growth. In some instances (United Kingdom and Canada), it does exhibit a negative effect, presumably due to a large crowding out effect. Likewise, an increase in tax revenue did not exhibit any negative effect in the United Kingdom and Canada, but it does have a significant negative effect on GDP growth in the United States economy.
\end{abstract}

Keywords: government size, tax revenue, economic growth, United Kingdom, USA, Canada

\section{Introduction}

The relationship between government size and economic growth has been a heavily debated issue among scholars for over five decades. The curiosity to determine which factors contribute to growth lies in the definition of growth as a measure of economic prosperity. Growth is calculated by measuring annual changes in a country's real GDP, or the inflation-adjusted value of all goods and services produced within an economy within a given year. Simply put, a growing economy is a healthy economy, and scholars, politicians, and economists have been trying for more than half a century to apply a deterministic approach to the growth challenge (Barro, 1999). There are two perspectives on government spending in today's discourse. Some believe that government spending enhances economic growth, postulating that an increase in the size of government positively affects economic growth. Others believe that government spending does not have any significant effect on economic growth, instead suggesting that government spending crowds out private investment, thereby reducing private sector output and employment levels.

Governments spend for a variety of reasons: to reduce inequality through social welfare, provide public services like fire and police departments, merit goods like healthcare and education, debt interest payments, transportation and infrastructure, and military spending. Without government funding, these crucial infrastructures would run the risk of collapse. Unfortunately, these services come with an ever-increasing price that is reflected in swelling national debts. This means that we spend more than we earn, and to compensate for the difference in balances, we must borrow from other countries, resulting in debt interest payments that further erode budgetary limitations in the future.

The road to economic prosperity has only recently been paved with good intentions. After World War II, policy experts began to express interest in the discipline now known as developmental economics. Theories on growth thereby became widespread, with several strains of growth theory emerging. Notably, three main perspectives can be identified (Bergh \& Henrekson, 2011): the neoclassical growth model, the endogenous growth model, and the view of institutions as determinants of growth.

The neoclassical growth model, enunciated by Solow (1957) and Swan (1956), proposed that capital yields diminishing returns to growth, as well as determined that the long-term growth rate is exogenous, concluding 
that increases in taxes negatively affect GDP growth by reducing aggregate demand. Barro (1990) and Romer (2011), respectively, developed the endogenous growth model, which featured no diminishing returns, thereby allowing the level of technology to affect long-run per capita growth, addressing a key shortcoming of the neoclassical model. Barro and Romers's model also showed that tax distortion had far more extensive effects on growth than the neoclassical model revealed, in addition to promoting productive government spending as a remedy to offset taxation through education and healthcare, potentially leading to higher long-term growth. In both models, capital is referred to as a broad definition that includes human capital.

From these two models emerged the notion of institutions as determinants of growth, where governments are considered as fundamental to growth. This idea claims that the main function of government is to maintain transparency through the development of laws and property rights conducive to growth. Spending on military and policing removes the responsibility of personal defense from the individual, allowing the individual to engage in activities for which he is better suited, maximizing productivity. Studies following works like North (1987) have confirmed that institutional arrangements usually enforceable only by governments, such as rules of law and property rights, are crucial to maintaining increasing levels of growth.

These three perspectives are woven tightly together by governments across the globe. The aforementioned theories were accepted by governments and politicians alike, both eager to influence their odds at prosperity. Expenditures rose at an increasing rate during the latter half of the 20th century, causing budget deficits whose weight continues to impede the very growth those engaged in spending were seeking.

Particularly after the financial market collapse of 2008, an interest in the size of government has reemerged. Proponents of larger government emphasize that governments can contribute positively to economic growth by building infrastructure, creating regulations, and improving social welfare. The purpose of this research is to study the effect of the size of government on economic growth in three OECD countries, namely the United States, United Kingdom, and Canada. We hope that the results of this inquiry will shed some light on the relationship between government spending and economic growth.

\section{Review of Literature}

Government involvement has an indisputable role in influencing a country's economy. A lack of consensus on how to quantify this involvement is what creates today's literature's divide in findings. Early cross-country studies measured government size using a variety of metrics, including, but not limited to, public consumption spending, total expenditure, social expenditure, and tax and expenditure as a share of GDP (Cameron, 1982; Marlow, 1986; Carr, 1989; Agell et al., 1997). This data may have been further convoluted in accounting for real versus nominal figures, total output versus per capita, purchasing price parities, exchange rates, and ratios versus growth. These inconsistencies in data prevent the establishment of a basis for comparison, prompting our careful consideration during data collection.

Previous studies also rarely take into account variations that result from gathering data from countries that have significant divides in income, output, size, and types of government, among various other factors. For example, Ram (1986) uses a cross-sectional and time series data for 1960-1970 and 1970-1980 concludes that government size has a positive effect on economic performance and growth. He further concludes that government size has a positive externality effect on the rest of the economy and the factor productivity was higher in the government sector than in the rest of the economy during 1960s. His finding essentially argues that the public sector is more efficient than the private sector which can be hard to accept. Landau's (1993) study, for example, collected data from a sample of 104 countries, ranging from Rhodesia to the United States. Therefore, our model is designed to draw conclusions from countries that are comparable demographically.

The determinants of growth are fundamentally reduced to the notion that output is a function of the amount of capital and labor in an economy, which yields a certain level of productivity or level of output. This level of output can then only be improved by changes in technology that allow greater productivity, as summarized by the Solow growth model. This growth model serves as the basis for our theoretical model.

However, the labor market and level of capital are variables that are very sensitive to exogenous factors, such as government expenditure, in turn impacting growth. Johnson and Mason (2012) argued that poverty is inextricably linked to the labor market, insofar as the cyclical changes in the economy cause joblessness to fluctuate, at times driving poverty. Antipoverty programs and social transfer payments, a component of government expenditure, not only enable individuals to persist in poverty, but in doing so, also impact the supply of labor by dis-incentivizing those who are unemployed to seek employment. In this regard, government expenditures reduce the amount of available labor, which in turn negatively impacts an economy's productivity, thereby negatively affecting output. 
Government spending is made possible by tax revenue. When government expenditures rise, taxation must also rise to supply additional revenue for the increase in spending. Taxation, particularly on income, acts as a disincentive to workers to produce more output, as their financial benefit lessens as they earn more. For example, if marginal tax rates rise, a person may choose to work fewer hours, learn fewer more productive skills, or work at a lower intensity in an effort to lower their taxable income (Bergh \& Henrekson, 2011).

In an analysis of the unemployment and poverty rate between 1967 and 2010 in the United States, Johnson and Mason (2012) determine that periods of unemployment are accompanied or followed by periods of increasing poverty, which translates into less output. These findings suggest a connection between changes in the labor markets and the growth and productivity of an economy, which we argue is further eroded by rises in government expenditure.

As Johnson and Mason perceptively note, if a growing economy stimulates job growth in a way that reduces poverty, doing so is appealing because it avoids the taxation necessary to fund antipoverty initiatives.

\section{Theoretical Background, Methodology, and Data}

The factors of production and production technology determine the level of output in an economy, which is represented by the production function:

$$
Y=f(K, L)
$$

Where Y represents the output level (real GDP), K represents the amount of capital, and L representing the amount of labor. Assuming constant technology, increases in either the amount of capital or labor should increase output in the economy.

After adding government expenditure (GE) and tax revenue (t), equation (1) can be rewritten as:

$$
Y=f(K, L, G E, T)
$$

We expect the coefficients of $\mathrm{K}$ and $\mathrm{L}$ to be positively related to Y. However, as discussed above, studies debate the efficacy of government expenditure and taxation on growth. Given the most recent literature connecting government expenditure and taxation as negative influences on growth, we expect GE and to have a negative effect on the level of output, and ultimately, real GDP growth rate.

As indicated above, this study uses a set of annual time series data from three OECD countries, namely the United States, United Kingdom, and Canada, from 1975 to 2012 to establish the effects of total tax revenue and government expenditure on growth. Our dataset was compiled from OECD, World Development Indicator, and Bureau of Economic Analysis databases. We have thirty-seven observations for each country in our first estimation, and thirty-six observations in our second estimation. The definition and detail source of data are reported in Appendix.

\section{Empirical Findings and Analysis}

The statistical form of equation (2) is as follows:

$$
\dot{y}=\beta_{0}+\beta_{1} K+\beta_{2} L+\beta_{3} G E+\beta_{4} T+e
$$

Where $\dot{y}$ is growth rate, or the annual percentage change in real GDP, $\mathrm{K}$ is gross fixed capital formation as a percentage of GDP, GE is government expenditure as a percentage of GDP, T is tax revenue as a percentage of GDP, and e is the random error term. As indicated above, the coefficients of $\mathrm{K}$ and $\mathrm{L}$ are expected to be positive. The coefficient of GE will be positive if government expenditure positively affects output. The coefficient of $\mathrm{T}$ will be negative is tax revenue negatively affects growth.

Our initial estimation showed that our Durbin-Watson values fell within the inconclusive range. Therefore, in order to correct for possible autocorrelation, AR (1) is added as another explanatory variable.

The model developed is as follows:

$$
\dot{y}=\beta_{0}+\beta_{1} K+\beta_{2} L+\beta_{3} G E+\beta_{4} T+A R(1)
$$

The estimation of equations (3) and (4) are reported in Table 1.

When the data sets are estimated with the addition of an AR(1) term as an additional explanatory variable, The coefficients of AR(1) terms are statistically significant at the conventional level in all estimations and the F-statistic for the United States is 6.34, 3.32 in Canada, and 5.46 in the United Kingdom, all of which are significant at the .01 critical level, strongly support our use of the AR(1) term. The corrected regression explains 43, 25, and 39 percent of the variation in the dependent variable in the United States, Canada, and United Kingdom, respectively, while the original regression explains only 28, 10, and 32 percent, respectively. 
As seen in Table 1, in the United States, capital carries a positive coefficient in both of our estimations. The coefficient of 0.83 is statistically significant at the .05 level in our first estimation, and the coefficient of 1.77 is statistically significant at the .01 level in our second estimation. These findings indicate that an increase in capital, holding all other things constant, contributes a positive effect on economic growth. Regarding labor, we find that the coefficient is positive and statistically significant at the .10 level only in the case of the United States. In the case of Canada and the United Kingdom, the coefficient carries a negative sign, but is not statistically significant from zero.

Our focuses of interest in this study are the coefficients of government expenditure (GE) and tax revenue (t). As far as GE is concerned, increases in size of government expenditure did not show any positive effect in the United States. However, in the case of Canada and the United Kingdom, we find its effect to be negative.

These findings suggest that in Canada and the United Kingdom increases in government size could be attributed to a large crowding out effect on private investment, offering an explanation for the negative effect of government expenditure on economic growth our findings put forward.

Regarding tax revenue, we find that in the United States, the coefficient of 0.83 is negative and statistically significant at the .05 level. The estimated parameter suggests that a $1 \%$ increase in tax revenue as a percentage of GDP lowers real GDP growth rate by $0.84 \%$ in the United States. For Canada and the United Kingdom, the coefficients are negative, as expected, albeit not statistically significant.

\section{Summary and Conclusions}

Our findings suggest that government size may negatively impact growth. In the United States, our estimation results indicate that increases in gross fixed capital formation positively impact growth, whereas increases in tax revenue (a measure of government size) would negatively impact growth. Total government expenditure does not have a statistically significant impact on growth.

In Canada, output shows to be statistically significantly impacted by increases in gross fixed capital formation. Effects of government expenditure and tax revenue on growth rate are negative, albeit statistically insignificant.

In the United Kingdom, increases in government expenditure reveal a negative and statistically significant impact on growth, with increases in gross fixed capital formation and tax revenue exhibiting no effect on economic growth.

In terms of policy objectives, we suggest that governments become more strategic in their spending by restructuring taxes and expenditure to maximize effects on growth. Moreover, government expenditure may contribute less significantly to increasing growth if allocated inefficiently to projects or crowds out private investment, confirming findings in a similar study by Afonso and Furceri (2008). These findings should be useful to policy makers who embark on the task of allocating budgetary spending and limitations, namely to redirect spending towards more growth enhancing activities.

\section{References}

Afonso, A., \& Furceri, D. (2008). Government Size Composition, Volatility and Economic Growth. Working Paper Series, Frankfurt: European Central Bank.

Agell, J., Lindh, T., \& Ohlsson, H. (1997). Growth and the Public Sector: A Ccritical Review Essay. European Journal of Political Economy, 13, 33-62. http://dx.doi.org/10.1016/S0176-2680(96)00031-6

Barro, J. (1990). Government Spending in a Simple Model of Endogenous Growth. Journal of Political Economy, 98, 103-125. http://dx.doi.org/10.1086/261726

Barro, J. (1999). Determinants of Economic Growth: A Cross-Country Empirical Study. Cambridge, Massachusetts: MIT Press.

Bergh, A., \& Henrekson, M. (2011). Government Size and Growth: A Survey and Interpretation of the Evidence. Journal of Economic Survey, 25, 872-897. http://dx.doi.org/10.1111/j.1467-6419.2011.00697.x

Cameron, D. (1982). On the Limits of Public Economy. Annals of Academy of Political and Social Science, 459, 46-62. http://dx.doi.org/10.1177/0002716282459001004

Carr, J. L. (1989). Government Size and Economic Growth: A New Framework and Some Evidence from Cross-Section and Time-Series Data: Comment. The American Economic Review, 79, 267-271. Retrieved from

http://www.gpo.gov/fdsys/search/pagedetails.action?granuleId=\&packageId=BUDGET-1996-BUD\&fromB rowse $=$ true 
Johnson, C. K., \& Mason, P. L. (2012). Theories of Poverty: Traditional Explanations and New Directions. In P. N. Jefferson (Ed.), The Oxford Handbook of the Economics of Poverty (pp. 105-138). New York: Oxford University Press.

Landau, D. (1993). Government Expenditure and Economic Growth: A Cross-Country Study. Southern Economic Journal, 49, 783-792. http://dx.doi.org/10.2307/1058716

Marlow, M. (1986). Private Sector Shrinkage and Growth of Industrialized Economies. Public Choice, 49, 143-154. http://dx.doi.org/10.1007/BF00181036

North, D. C. (1987). Institutions, Transaction Costs, and Economic Growth. Economic Inquiry, 25, 419-428. http://dx.doi.org/10.1111/j.1465-7295.1987.tb00750.x

Office of Management and Budget. (1995). Budget of the U.S. Government, Budget of the United States Government. Fiscal Year 1996, Washington D.C.

Ram, R. (1986). Government Size and Economic Growth: A New Framework and Some Evidence from Cross-Section and Time-Series Data. The American Economic Review, 76, 191-203.

Romer, P. (2011). Endogenous Growth. Advanced Macroeconomics (4th ed., pp. 101-149). New York: McGraw-Hill.

Solow, R. M. (1957). Technical Change and the Aggregate Production Function. Review of Economics and Statistics, 39(3), 312-320. http://dx.doi.org/10.2307/1926047

Swan, T. W. (1956). Economic Growth and Capital Accumulation. Economic Record, 32(2), $334-361$. http://dx.doi.org/10.1111/j.1475-4932.1956.tb00434.x

Table 1. Estimation of the model; dependent variable $\dot{y}$

\begin{tabular}{|c|c|c|c|c|c|c|}
\hline \multirow[b]{2}{*}{ Variable } & \multicolumn{2}{|c|}{ United States } & \multicolumn{2}{|c|}{ Canada } & \multicolumn{2}{|c|}{ United Kingdom } \\
\hline & $(1)$ & $(2)$ & $(1)$ & $(2)$ & $(1)$ & $(2)$ \\
\hline \multirow[t]{2}{*}{ Const. } & -8.0403 & $24.2459 * * *$ & -0.3032 & 16.5097 & 9.9317 & 13.0975 \\
\hline & $(-1.6511)$ & $(-3.5833)$ & $(-0.0259)$ & $(0.8098)$ & $(0.8628)$ & $(0.8508)$ \\
\hline \multirow[t]{2}{*}{ K } & 0.83803 & $1.7729 * * *$ & 0.2783 & $0.6401^{*}$ & $0.3421^{*}$ & 0.3441 \\
\hline & $(2.5825)$ & $(4.4125)$ & $(1.4604)$ & (1.9837) & (1.8904) & $(1.2407)$ \\
\hline \multirow[t]{2}{*}{$L$} & 0.7455 & $3.7946^{*}$ & $-2.28 \mathrm{E}-05$ & $-6.61 \mathrm{E}-07$ & -0.0001 & $-4.17 \mathrm{E}-05$ \\
\hline & $(0.5415)$ & $(1.6925)$ & $(1.1326)$ & $(-0.0474)$ & $(-1.6319)$ & $(-0.5826)$ \\
\hline \multirow[t]{2}{*}{$G E$} & -0.007 & 0.1584 & -0.3456 & -0.9648 & $-0.7142 * * *$ & $-0.8233 * * *$ \\
\hline & $(-0.0518)$ & $(0.8853)$ & $(-1.3854)$ & $(-1.6030)$ & $(-3.1347)$ & $(-2.2544)$ \\
\hline \multirow[t]{2}{*}{$T$} & -0.3871 & $-0.8391 * *$ & 0.3227 & -0.5456 & 0.0378 & -0.0025 \\
\hline & $(-1.1703)$ & $(-2.1259)$ & $(0.7648)$ & $(0.7648)$ & $(0.1458)$ & $(-0.0079)$ \\
\hline \multirow[t]{2}{*}{$A R(1)$} & - & $0.5278 * * *$ & - & $0.7414 * * *$ & - & $0.4085^{* *}$ \\
\hline & & (3.5378) & & $(4.9932)$ & & $(2.1867)$ \\
\hline Obs. & 37 & 36 & 37 & 36 & 37 & 36 \\
\hline Adj R-sq & 0.2818 & 0.4329 & 0.1047 & 0.2497 & 0.3261 & 0.3895 \\
\hline F-Stat & 4.5313 & 6.3425 & 2.0523 & 3.3295 & 5.3567 & 5.4651 \\
\hline D. W. & 1.2825 & 2.0309 & 1.3524 & 1.7596 & 1.4125 & 1.7319 \\
\hline
\end{tabular}

Note. Figures in the parentheses are t-statistics for corresponding coefficients. ${ }^{* * *}$ significant at $1 \%$ critical level, ${ }^{* *}$ significant at $5 \%$ critical level and * significant at $10 \%$ critical level.

\section{Appendix A}

Data and Their Sources

\begin{tabular}{cl}
\hline \multicolumn{2}{c}{ Definition of variables } \\
\hline$\dot{\boldsymbol{y}}$ & annual growth rate of real GDP \\
$\mathrm{K}$ & gross capital formation/investment as a percentage of GDP \\
$\mathrm{GE}$ & government spending as a percentage of GDP \\
$\mathrm{T}$ & total tax revenue as a percentage of GDP \\
$\mathrm{L}$ & working age (15-64) population growth rate \\
\hline
\end{tabular}




\begin{tabular}{ll}
\hline Data and their sources & \\
\hline United States & \\
$\dot{y}$ & OECD \\
$\mathrm{k}$ & OECD \\
$\mathrm{GE}$ & Bureau of Economic Analysis \\
$\mathrm{T}$ & Bureau of Economic Analysis \\
$\mathrm{l}$ & OECD \\
\hline Canada & \\
$\dot{\mathrm{y}}$ & World Development Indicator \\
$\mathrm{k}$ & World Development Indicator \\
$\mathrm{GE}$ & World Development Indicator \\
$\mathrm{t}$ & $1975-1990$ OECD, 1991-2012 World Development Indicator \\
$\mathrm{l}$ & $1975-1989$ OECD, 1990-2012 World Development Indicator \\
\hline United Kingdom & \\
$\dot{\boldsymbol{y}}$ & World Development Indicator \\
$\mathrm{k}$ & World Development Indicator \\
$\mathrm{GE}$ & World Development Indicator \\
$\mathrm{T}$ & $1975-1994$ OECD, 1995-2012 World Development Indicator \\
$\mathrm{l}$ & $1975-1989$ OECD, 1990-2012 World Development Indicator \\
\hline
\end{tabular}

\section{Copyrights}

Copyright for this article is retained by the author(s), with first publication rights granted to the journal.

This is an open-access article distributed under the terms and conditions of the Creative Commons Attribution license (http://creativecommons.org/licenses/by/3.0/). 